\title{
The Necessity for Alternative Legal Pathways: The Best Practice of Humanitarian Corridors Opened by Private Sponsors in Italy
}

\author{
Carola Ricci`(i)
}

(Received 09 February 2019; accepted 22 August 2019)

\begin{abstract}
The scope of this Article is to understand to what extent a recent and fruitful private initiative sponsoring a safe alternative legal pathway spread from Italy, called "humanitarian corridors," may in the future become a general and uniform alternative model for all the European Union States. Such a practice-which currently represents an exceptional route for vulnerable migrants to enter the country without harm after a security screening and to be materially supported by the same sponsors in the crucial initial phase of integration-is at present restricted to a relatively small number of beneficiaries, but it could potentially be extended to other States.

In order to achieve this goal, it is argued that the present model should be slightly adjusted—especially with regard to the actual reference to Article 25 of the Visa Code as its legal basis. The latter seems difficult to be formally maintained after the much criticized 2017 judgment $X$ and $X v$. Belgium, in which the Court of Justice of the European Union conferred to Member States a wide margin of discretion when requested to grant humanitarian visas by vulnerable people exposed to serious irreversible harm. Against this background, clear obligations to grant humanitarian visas to vulnerable people at risk already exist. This obligation stems from international law - both general and conventional—and constitutes the adequate legal basis both for States and civil society to act in a "multi-stakeholder alliance" to find solutions to the challenges and opportunities deriving from international migration, as indicated in the Global Compact for Migration.
\end{abstract}

Keywords: Migration; alternative legal pathways; humanitarian corridors; private sponsorship; Global Compact for Migration; Visa Code

\section{A. The International Commitment to Enhance Availability of Pathways for Regular Migration}

The development of legal pathways to serve as alternatives to perilous trips-managed by ruthless traffickers and smugglers - for vulnerable people attempting to safely access the territory of a host country is a specific commitment solemnly declared in the 2016 "New York Declaration for Refugees and Migrants" by all the UN Member States, willing to achieve such a goal also in cooperation with the civil society and the private sector. It specifically calls for "a deeper interaction between Governments and civil society to find responses to the challenges and the opportunities posed by international migration," a "multi-stakeholder alliance."

\footnotetext{
*Associate Professor of International Law, University of Pavia (Italy); PhD (University of Milan).

${ }^{1}$ G.A. Res. 71/1, New York Declaration for Refugees and Migrants (Sept. 19, 2016), respectively at: para. 61; para. 15, which reads as follows: "We invite the private sector and civil society, including refugee and migrant organizations, to participate in 
The same objective is expressly reaffirmed and developed within the Global Compact for Safe, Orderly and Regular Migration, the non-legally binding cooperative framework adopted during the intergovernmental conference held in Marrakech on December 10, 2018, which was formally endorsed some days later by the General Assembly on its seventy-third session. ${ }^{2}$

Among its different "cross-cutting and interdependent guiding principles" (point 15), ${ }^{3}$ the Global Compact specifically promotes a "whole-of-society" approach (litt. $j$ ), in the shared idea that safe, orderly and regular migration "works for all well when it takes place in a well-informed, planned and consensual manner" (point 13), in a spirit of "win-win cooperation, to address the challenges and the opportunities of migration in all its dimensions through shared responsibility and innovative solutions" (point 14), that should be consistent with international law (point 15, litt. d). The Global Compact clearly calls for a broad partnership with States and all the relevant stakeholders in migration governance, such as: Migrants and civil society; migrant and diaspora organizations; faith-based organizations; local authorities and communities; the private sector; trade unions; parliamentarians; national human rights institutions; the International Red Cross and Red Crescent Movement; academia; and the media (points 15, litt. $j$ and 44).

Such an approach encourages a sort of new "active and dialectic perspective" in migration related aspects between, on the one hand, the States-traditionally conceived both as the primary subjects of international law and primary duty-bearers - and, on the other hand, all the different "forces that hustle international law,"4 which might be referred to generally as non-State actors, but also as "ancillary duty-bearers." The specified common aim is to an open confrontation at all levels on alternative legal solutions to a phenomenon which is inherently transnational in nature and, as such, requires "consensus, collective ownership, joint implementation" (point 15, litt. b). This approach reconsiders the role of non-State actors in shaping innovative solutions to respect, fulfill, and protect the fundamental human rights of all migrants irrespective of their migration status (litt. $f$ ), while promoting the security and prosperity of all the communities involved. The private sector and civil society are identified as the closer entities to these migrant communities who would require an intervention, as the subsidiarity principle openly vindicates. In particular, civil society can operate at the same level in which the individuals live and cohabitate, enabling them to properly understand the actual situation of these migrants-in respect of the fulfilment and protection of fundamental rights - and to identify the most vulnerable groups within a community and advocate more effectively the needs of such communities which are considered as the collective dimension "in which alone the free and full development" of the personality of any individual is possible. From this basic principle, solemnly confirmed in the 1948 Universal Declaration

multi-stakeholder alliances to support efforts to implement the commitments we are making today" (emphasis added). Similarly, the Declaration refers to: "multi-stakeholder dialogue", at point 55; to "multi-stakeholder approach", at point 69 and in Annex I, at point 2. In the same vein, see also para. 85 and, within Annex II, para. 15; cf. Elspeth Guild, The UN's search for a Global Compact on Safe, Orderly and Regular Migration, 18 German L.J. 1779-95 (2018).

${ }^{2}$ On July 13, 2018, UN Member States finalized the text for the Global Compact for Safe, Orderly and Regular Migration which was adopted in Marrakech on 10 and 11 December 2018 (text available in all official languages at http://www.un.org/en/ conf/migration/), referring to the enhancement of "availability and flexibility of pathways for regular migration" as the fifth of its twenty-three main objectives. Few days later, the General Assembly endorsed the Global Compact adopted by the Marrakech Intergovernmental Conference; cf. G.A. Res. 73/195, Global Compact for Safe, Orderly and Regular Migration (Dec. 19, 2018).

${ }^{3}$ The principles inspiring the Global Compact, as indicated in its paragraph 15, often refers to non-State actors, for example when it underlines the aim of achieving the well-being of migrants as well as of the members of the countries of the communities of origin, transit and destination (litt. $a$ ), and the accountability of all States, of public and private institutions and entities, as well as of the individuals to laws that must be consistent themselves with international law (litt. $d$ ).

${ }^{4}$ Emmanuel Decaux, The Impact of Individuals and Other Non-State Actors on Contemporary International Law, in GLOBAL Justice, Human Rights and the Modernization of International Law, 3-16, at 10 (Riccardo Pisillo-Mazzeschi \& Pasquale De Sena eds., 2018). Cf. for the States' role as primary duty-bearers in realizing fundamental human rights, namely economic, social and cultural rights, see Committee on Economic, Social and Cultural Rights ("CESCR"), "General Comment No. 3, The Nature of State Parties' Obligations (Art. 2, para. 1, of the Covenant)”, E/1991/23 (Dec. 14, 1990). 
of Human Rights — specifically, Article 29, paragraph 1-and re-affirmed fifty years later in a specific declaration adopted per consensus by the General Assembly, ${ }^{5}$ it follows that all members of society, individuals, families, local communities, non-governmental organizations, civil society organizations, and the private business sector should be globally involved, through the States, in collective negotiations to share best practices and elaborate common rules. These should be agreed upon jointly in compliance with international law and in a manner conducive to respecting the fundamental rights of all migrants and their communities of origin, transit, and destination.

In the same vein, one of the main specific purposes of this multi-actors' approach sketched in the Global Compact consists of developing or building upon "existing national and regional practices for admission and stay of appropriate duration based on compassionate, humanitarian or other considerations for migrants compelled to leave their countries ... such as by providing humanitarian visas, private sponsorships ..." (point 21, litt. g), in order to allow these migrants to safely enter a host country and, at the same time, to empower them "to become active members of society and promoting the reciprocal engagement of receiving communities and migrants in the exercise of their rights and obligations towards each other" (point 32, describing the following objective 16). Finally, all the States committed themselves to fulfill these-and other-objectives and implement them at the global, regional, and local levels, "taking into account different national realities ... and respecting national policies and priorities," while reaffirming their will to implement it "in a manner that is consistent with our [States'] rights and obligations under international law" (point 41).

Along the same lines, a recent and fruitful private initiative sponsoring a safe alternative pathway spread from Italy. It currently represents an exceptional legal corridor for migrants that is jointly agreed upon by the Italian Government and different faith-based organizations. The beneficiaries are persons in a situation of vulnerability allowed to $(i)$ enter the country safely after a security screening - completed in advance by the Italian authorities on the basis of the information gathered in the host State-and to (ii) be materially supported by the same sponsors during the crucial initial phase of integration.

The scope of this Article is to understand to what extent such a practice for admission and stay of vulnerable people - which is currently restricted to a relatively small number of beneficiariescould potentially be extended to other communities and States_-namely, EU Member States—so as to become a general and uniform alternative model for the willing States and civil society that co-operate together to develop a multi-stakeholders' action at different levels and in compliance with international law rules, as upheld in the Global Compact.

\section{B. Best Practice of Private Sponsorship Comes to Italy: Aims and Formal Legal Basis}

Among the good practices adopted to allow persons requiring international protection to reach the country of destination in full legality and safety, the well-established Canadian model of

\footnotetext{
${ }^{5}$ G.A. Res. 53/144, Declaration on the Right and Responsibility of Individual, Groups and Organs of Society to Promote and Protect Universally Recognised Human Rights and Fundamental Freedoms (Dec. 9, 1998). Similar considerations can be found in Committee on Economic, Social and Cultural Rights ("CESCR"), General Comment No. 12, The Right to Adequate Food (Art. 11 of the Covenant), E/C.12/1999/5 (May 12, 1999), para. 20 ("While only States are parties to the Covenants and are thus ultimately accountable for compliance with it, all members of society, individuals, families, local communities, nongovernmental organizations, civil society organizations, as well as the private business sector have responsibility in the realization of fundamental rights. States should provide an environment that facilitate implementation of these responsibilities"). As underlined by Decaux, supra note 4, at 7-8, the original wish of "the international law's pioneers" at the end of the nineteenth Century for a real co-making of law, meant "not only 'traité-loi', but collective negotiations between 'social partners,"” a two-pillar model of political society and civil society, which was never realized-not even for ILO and UNESCO- "since States are unwilling to lose their monopoly on legal force, the overhang position of the rulers over the governed." This is evidenced in the Author's opinion also by the circumstance that every reference to non-State actors falls at present only under soft law "as if a fundamental asymmetry exists."
} 
private sponsorships ${ }^{6}$ has inspired in Italy a rather sui generis initiative to enable the entrance of at least 3,100 refugees over a period of three and a half years. For the most part, the beneficiaries are Syrian citizens, coming from Lebanon, that have been recently joined by other vulnerable people arriving from Ethiopian camps while fleeing from the neighboring countries in the Horn of Africa-Eritrea, South Sudan, Somalia, and Niger.

These legal alternative pathways, referred to by their sponsors as "humanitarian corridors,"7 have been opened on the basis of three hybrid Memoranda of Understanding ("MoU").

The first Memorandum was concluded on December 15, 2015, by the Italian Ministries for Foreign and Internal Affairs, on the institutional side, and the Community of Sant'Egidio, the Federation of Protestant Churches, and the Waldesian Board on the private side. The Memorandum aimed to open humanitarian corridors with priority from Lebanon. ${ }^{8}$

The second Memorandum was adopted on January 12, 2017, by the Italian Ministries of Foreign and Internal Affairs, on the one hand, and on the other hand, the Italian Bishops' Conference-CEI, acting through the Caritas and the Migrantes Foundation-and the same Community of Sant'Egidio, on the sponsors' side, aiming to extend the initiative to the refugee camps in Ethiopia as well. ${ }^{9}$

\footnotetext{
${ }^{6}$ The Canadian model of private sponsorship, still offering a complementary tool for State reception and resettlement policies, was initially elaborated in order to give a prompt response to the emergency situation resulting from two waves of refugees caused by the Indo-Chinese crisis in the 1970s and 1980s and originally codified in the 1978 Immigration Act. See Gregor Noll \& Jessica Fagerlund, Safe Avenues to Asylum? The Actual and Potential Role of EU Diplomatic Representations in Processing Asylum Requests. A Study Conducted within the Framework of the Refugee Research Programme at the Danish Centre for Human Rights 13, 80-88 (2002), available at https://www.unhcr.org/3cd000a52.pdf (last visited Aug. 6, 2019). See also W. Courtland Robinson, Terms of Refuge: The Indochinese Exodus And THE InTERnational Response 138-42 (1998); Ekaterina Yahyaoui Krivenko, Hospitality and Sovereignty: What Can We Learn From the Canadian Private Sponsorship of Refugees Program?, 24 INT'L J. REFUGEE LAW 579-602 (2012); Meltem Ineli-Ciger, An Examination of the Comprehensive Plan of Action as a Response to Mass Influx of 'Boat People': Lessons Learnt for a Comprehensive Approach to Migration by Sea, in 'BOAT REFUGEEs' AND Migrants at Sea: A Comprehensive Approach, Integrating Maritime Security and Human Rights 400-16, spec. 412 (Violeta Moreno-Lax \& Efthymios Papastavridis eds., 2016).

${ }^{7}$ On the definition of "humanitarian corridors" used by the sponsors of the initiative, the absence of any reference to the formal and technical expression generally utilized by international organizations dealing with asylum and migration has been noted by Paolo Morozzo della Rocca, I due protocolli d'intesa sui "corridoi umanitari" tra alcuni enti di ispirazione religiosa ed il governo ed il loro possible impatto sulle politiche di asilo e immigrazione, DIRITTO, IMMIGRAZIONE E CITTADINANZA 1-31, esp. 10 (2017). The text of the Memoranda under comment are not available to the public: That is why I am particularly grateful to the Community of Sant'Egidio for providing me with a copy thereof. For further comments on the first MoU, see also Marco Impagliazzo, Le vie dell'integrazione 'latina', LIMEs 127-29 (2016); Mirko Sossai, Canali di ingresso legale sicuro dei migranti in Europa: il modello dei "corridoi umanitari", VERGOGNA ED ESClUSIONE. L'EUROPA DI FRONTE ALLA SFIDA DELL'EMIGRAZIONE 75-89 (Umberto Curi ed., 2017); Lucrezia Colmayer \& Michela Signorini, I corridoi umanitari, possibili alternative di ingresso legale in Italia, 281 IMMIGRAZIONE.IT (2017); Antonio Mutti, L'importanza dei corridoi umanitari, LA RIVISTA IL Mulino (2017), https://rivistailmulino.it/item/3777 (last visited Aug. 6, 2019).

${ }^{8}$ According to data released by the Community of Sant'Egidio and by the news agency of the Federation of Protestant Churches in Italy, in the first three-and-a-half years, a number of 1,650 refugees - the majority of which were Syrian-have arrived from Lebanon through this legal and safe way. See the recent survey, published by Community of Sant'Egidio (June 27, 2019), Corridoi umanitari in Europa. Dossier sui corridoi umanitari in Italia, Francia, Belgio e Andorra. Storia e numeri, available at https:/www.santegidio.org//downloads/Dossier-Corridoi-Umanitari-20190627-web.pdf (last visited Aug. 6, 2019). The first Memorandum also provided for an expansion to Morocco that apparently did not occur, see SANTE'EGIDIO, http://www. santegidio.org (last visited Aug. 6, 2019); FCEI, http://www.nev.it (same); CHIESA EvangeliCA VALDESE, https://www. chiesavaldese.org (same).

${ }^{9}$ The second Memorandum of Understanding, signed in Rome on January 12, 2017—and financed by funds derived from the "Otto per Mille" gathered in Italy among free contributors in favor of CEI and of the Community of Sant'Egidio-provides for the transfer within eighteen months of 500 Eritrean, Somali, and South-Sudanese citizens from refugee camps in Ethiopia, chosen both for its role as a "transition country" and for the presence in its territory of NGOs and churches already committed to supporting refugees. As of June 27, 2019, the vulnerable people who have arrived from Ethiopia number 498, and are composed of $90 \%$ families and more than $40 \%$ minors. Cf. Corridoi umanitari in Europa, supra note 8 , at 7.
} 
All the involved associations are bearing entirely the costs connected with these laudable and courageous initiatives. These pilot-projects have been both confirmed and extended after they first successfully passed a sustainability assessment test. The commitment to double the efforts has been upheld by the same ecumenical associations that have promoted the first two projects. In particular, on November 7, 2017, just some days after the arrival of the sixteenth refugees' flight which reached the first 1,000 beneficiaries, the Foreign and Internal Ministries, the Community of Sant'Egidio, the Federation of Protestant Churches, and the Waldesian Board confirmed the first MoU to bring to Italy - for the most part from Lebanese camps - another 1,000 people in two years on a condition of "vulnerability." Similarly, on May 3, 2019, the second MoU-between CEI and Community of Sant'Egidio - was extended for further 600 visas from Ethiopia, Niger, and Jordan. ${ }^{10}$

At the moment, the Italian projects involve relatively small numbers when compared to the overall needs. Nonetheless, on the one hand, more than 2,000 safe entries were already made possible "par avion" from Lebanon and Ethiopia and are even now comparable to the resettlement quotas registered in other Member States. On the other hand, the model offers remarkable potential of expansion and represents "a challenge for Governments and the EU to go further."11 The example of Canada may be relevant in this regard as well. Despite its different critical aspects and the still pending demand for reform, ${ }^{12}$ between November 2015 and July 2017, this system allowed almost 19,000 Syrian citizens to join the country through private sponsorships, ${ }^{13}$ activated by both associations and individuals meeting basic requirements identified by the State in a clear, transparent, and easily accessible way. ${ }^{14}$

The Italian agreements have set up highly peculiar procedures for the protected entry of refugees and migrants, ${ }^{15}$ as already evident from the definition of the main intended goals. The first

\footnotetext{
${ }^{10}$ See again for more details on the numbers of beneficiaries Corridoi umanitari in Europa, supra note 8, at 7. Most of the funds for the projects come from the "Otto per Mille" system of the Waldensian Church-through the Diaconal Commission of the Waldensian Church - the Community of Sant'Egidio and the Federation of Protestant Churches, as well as from other fundraising initiatives, such as the one launched by the Community of Sant'Egidio. The third initiative has been supported also by the German Protestant Churches through the fundraising initiative of the traditional "Kirchentag" held in May 2017, see La Colleta del Kirchentag a Mediterranean Hope e SOS Méditerranée, MediterRanean Hope (Feb. 20, 2018), https://www. mediterraneanhope.com/2018/02/20/la-colletta-del-kirchentag-a-mediterranean-hope-e-sos-mediterranee/ (last visited Aug. 6 , 2019). The "vulnerability" of the new Memorandum of understanding is defined, similarly to the second agreement, in a wider and more inclusive way (Art. 3). The temporary humanitarian visa is, furthermore, granted "within the limits provided for by the legislation in force" pursuant to Art. 4, even if a reference to Art. 25 of the Visa Code is nevertheless made in the Preamble, point 10, litt. $c$. The refugees from the African countries are destined as well to grow in numbers, thanks to the confirmation, through the extension of the second memorandum decided in May 2019, of the sponsorship by CEI and the Community of Sant'Egidio. Every reference to the latter in text must be referred to the May 2019 MoU as well.

${ }^{11}$ See Morozzo della Rocca, supra note 7, at 10.

${ }^{12}$ The Canadian Council for Refugees has recommended a revision of the Programme which would allow, inter alia, the elimination of the existing restrictions on the regions of provenance of the beneficiaries and the yearly maximum threshold and the re-integration of the Federal Healthcare Programme to pay the basic medical expenses of non-Syrian refugees which, since 2012, are not subsidized anymore. See Renewing Canada's Private Sponsorship of Refugees Program, CANADIAN TCUT:(@):TPASTE:(@)OUNCIL FOR REFUGEES, https://ccrweb.ca/sites/ccrweb.ca/files/renewing-psr-jan-2016.pdf (last visited Aug. 6, 2019); Private Sponsorship of Refugees in 2017, CANADIAN COUNCIL FOR REFUGEES, https://ccrweb.ca/en/privatesponsorship-refugees-2017 (same).

${ }^{13}$ More precisely, this regards 18,865 of a total of 47,735 Syrian citizens, with another 24,420 directly assisted by the Government and 4,445 that arrived through mixed programs. For a detailed overview, see data released by the Department of Immigration, Refugees and Citizenship, Canada - Admissions of Syrian Refugees by Province/Territory and Census Metropolitan Area (CMA) of Intended Destination and Immigration Category, November 4th, 2015 - July 31st, 2017, Department of Immigration, Refugees And Citizenship, available at http://www.cic.gc.ca and https:// gocanadaonline.com (last visited Aug. 6, 2019).

${ }^{14}$ Minimum instructions on how to propose as a sponsor or beneficiary, or both, in the Canadian system are presented in the Private Sponsorship of Refugees Toolkit, CANADIAN COUNCIL FOR REFUGEES, available at http://ccrweb.ca/en/privatesponsorship-refugees and https://ccrweb.ca/en/private-sponsorship-refugees (last visited Aug. 6, 2019).

${ }^{15}$ For a definition of protected entry procedures, see inter alia Executive Committee of the High Commissioner's Programme, Complementary Forms of Protection: Their Nature and Relationship to the International Refugee Protection
} 
common objective is to ensure the arrival in Italy of "potential beneficiaries of international protection, and more specifically of the most vulnerable subjects" in a legal and safe manner from third party countries where they are located, at the expense of the abovementioned religious communities (Article 2 of the first, second and third MoU). In addition, these memoranda also ensure the first reception, by these same communities, in a way that may effectively support the process of "socio-cultural integration for an adequate length of time" (Article 4, second paragraph of the three MoUs).

A further aim of the three agreements is to "stabilize in Italy" the beneficiaries who also can profit from the necessary legal assistance from sponsors and to request international protection once the migrants have arrived in the country. The project, as such, looks at "excluding or limiting any secondary and voluntary movement" towards other countries, ${ }^{16}$ because-as detailed belowpotential beneficiaries are required to express a clear and univocal intention to that effect already in the selection phase. When these vulnerable people arrive, their dossiers are transmitted to the Italian delegation in the country of first asylum-Lebanon or Ethiopia-and then subjected to security checks by the Italian Ministries of Foreign and Internal Affairs. In the absence of any ground for rejection, the Italian authorities may issue a temporary visa and allow beneficiaries to fly safely to Italy. Once arrived in the country, NGOs launch the reception and integration phase that they have been granted for at least one year, at their total expense, while at the same time commencing the formal procedure for requesting international protection to Italian authorities (Article 4, litt. $d$ of the first MoU and point 11, litt. $c$ of the initial recitals of the second MoU, and points 10 litt. $d$ and 11 of the third MoU).

As for the legal basis for allowing the issuance of the visa, each Memoranda makes reference to Article 25 of the Regulation (EC) No. 810/2009-the so-called Visa Code. ${ }^{17}$ This provision derogates from the principle of fulfillment of the conditions of the Schengen Borders Code, ${ }^{18}$ thus allowing each Member State to issue a visa where national authorities deem it necessary "for humanitarian reasons or national interest reasons or by virtue of international obligations." Such a visa has a "limited territorial validity" ("LTV") within national borders for no more than 90 days, over a total period of 180 days, with the exception of cases where other Member States have agreed to extend its validity to their territories. ${ }^{19}$

In particular, following the judgment $X$ and $X v$. Belgium rendered by the EU Court of Justice on March 7, 2017, and even after the amendments recently introduced to the Visa Code by Regulation (EU) 2019/1155 of 20 June $2019,{ }^{20}$ it seems to be appropriate to avoid maintaining

Regime, U.N. Doc. EC/50/SC/CRP.18 (June 9, 2000), 4-5; Noll \& FAGERLUND, supra note 6, at 14-21; JANE MCADAM, Complementary Protection in International Refugee Law 19-51 (2007); Guy S. Goodwin-Gill \& Jane McAdam, The Refugee in International Law 285-345 (3d ed. 2007).

${ }^{16}$ This goal is explicitly stated in Art. 3, last paragraph of the second Memorandum.

${ }^{17}$ Regulation (EC) No. 810/2009 of the European Parliament and the Council of 13 July 2009 establishing a Community Code on Visas (Visa Code), 2009 O.J. (L 243) 1. See ex multis Steve Peers et al., Asylum Procedures, in EU IMmigRATION AND Asylum Law (Text and Commentary) Volume 3: Asylum Law 251 (Steve Peers et al., 2d rev. ed. 2015).

${ }^{18}$ Reference is made here to the conditions laid out in Art. 5, para.1, letters $a, c, d, e$ of the Schenghen Borders Code, first adopted on March 15, 2006, with Regulation (EC) No. 562/2006 of the European Parliament and the Council establishing a Community Code on the rules governing the movement of persons across borders, 2006 O.J. (L 105) 1. This was recently transposed in Art. 6 of the consolidated version of Regulation (EU) 2016/399 of the European Parliament and the Council of 9 March 2016 on a Union Code on the rules governing the movement of persons across borders (Schenghen Borders Code), 2016 O.J. (L 77) 1.

${ }^{19}$ On that debated provision, see the detailed study commissioned by the Civil Liberties, Justice and Home Affairs of the European Parliament, Ulla Ibsen Jensen, Humanitarian Visas: Option or Obligation? Study for the LIBE Committee, 68 CEPS PAPER IN LibERTY AND SECURITY IN EUROPE (2014), http://www.europarl.europa.eu/RegData/etudes/STUD/2014/509986/ IPOL_STU(2014)509986_EN.pdf.

${ }^{20} \mathrm{Cf}$. Case C-638/16, $X$ and $X v$. État belge (Mar. 7, 2017), ECLI:EU:C:2017:173, which, in contrast to widespread expectations, did not confirm the Opinion of Advocate General Mengozzi (Feb. 7, 2017), ECLI:EU:C:2017:93. Among the first comments, see Violeta Moreno-Lax, Asylum Visas as an Obligation under EU Law: Case PPU C-638/16 X, X v Belge (Part I and II), EU Migration L. Blog (16 and 21 February 2017), at http://eumigrationlawblog.eu (last visited Aug. 6, 2019); Jean-Yves 
at present the reference to Article 25 of the Visa Code in the Italian Memoranda for reasons that will be clarified below. Moreover, there are already clear obligations binding both States and nonState actors stemming from international general law and treaties that constitute an adequate legal basis, which seem to indicate that reference to that provision appears not only risky, but also redundant.

\section{The Beneficiaries of a Sui Generis Protection}

The Memoranda leaves the selection of the potential beneficiaries to the NGOs themselves, who autonomously prepare for each applicant an individual dossier by collecting the necessary information directly on the ground, particularly in the Lebanese and Eritrean camps where the refugees have found shelter. Therefore, the sponsors-present in the camps and fully aware of the context in which they are operating - have the responsibility to examine the potential beneficiaries and restrict them to a list of candidates in accordance with the criteria set out in the Memoranda (Article 3 of all the MoUs).

Beneficiaries may not only be those "persons considered by the UNHCR as deserving, at least prima facie, the recognition of the status of refugee" pursuant to the 1951 Geneva Conventionand its 1967 implementing Protocol. Therefore, the beneficiary could not only be the person that "owing to well-founded fear of being persecuted for reasons of race, religion, nationality, membership of a particular social group or political opinion, is outside the country of his/her nationality and is unable or, owing to such fear, is unwilling to avail himself/herself of the protection of that country; or who, not having a nationality and being outside the country of his/her former habitual residence is unable or, owing to such fear, is unwilling to return to it" (Article 1A(2) of the 1951 Geneva Convention as modified by Article 1(2) of the 1967 Protocol), but also those individuals potentially seeking protection because of their condition of objective vulnerability (Article 3 , litt. $a$ of all the MoUs).

Indeed, the project falls within the already known scheme of Protected Entry Procedures ("PEPs"), that are supplementary to the system set out by the 1951 Geneva Convention, in order to ensure an alternative legal pathway to persons in need and objectively vulnerable that do not fall within the definition of "refugees or who lack the recognition of such a status. This may happen not only in the manifold cases connected to situations of humanitarian emergencies that

Carlier \& Luc Leboef, The X. and X. case: Humanitarian visas and the genuine enjoyment of the substance of the rights, towards a middle way?, EU MigRATION L. BLOG (Feb. 27, 2017) (same, also published in a reduced version within the review Droit européen des migrations, JOURNAL DE DROIT EUROPÉEN 111-13 (2017)); Margarite Zoetewij-Turhan \& Sarah ProginTheuerkauf, AG Mengozzi's Opinion On Granting Visas to Syrians From Aleppo: Wishful Thinking?, EUR. L. BLOG (Feb. 14, 2017), at http://europeanlawblog.eu (last visited Aug. 6, 2019); Margarite Zoetewij-Turhan \& Sarah Progin-Theuerkauf, CJEU Case C-638/16 PP, X and X - Dashed Hopes for a Legal Pathway to Europe, Eur. L. BLog (March 10, 2017) (same); Evelien Brouwer, The European Court of Justice on Humanitarian Visas: Legal integrity vs. political opportunism?, 9 CEPS PAPER (Mar. 16, 2017); Francesca Spinelli, Sui visti umanitari per i profughi la battaglia ì ancora aperta, in INTERNAZIONALE (Mar. 24, 2017); Helena De Vylder, $X$ and X v. Belgium: a missed opportunity for the CJEU to rule on the State's obligations to issue humanitarian visa for those in need of protection, THE STRASBOURG OBSERVERS BLOG (Apr. 14, 2017), at http://strasbourgobservers.com (last visited Aug. 6, 2019); Giulia Raimondo, Visti umanitari: il caso X e X contro Belgio, C-638/16PPU, SIDI Blog (May 1, 2017), at www.sidiblog.org; Adele Del Guercio, La sentenza X. e X. della Corte di Giustizia sul rilascio del visto umanitario: analisi critica di un'occasione persa, 2 EUROPEAN PAPERs 271-91 (2017); Chiara Favilli, Visti umanitari e protezione internazionale: cosi vicini cosi lontani, in DIRITTI UMANI E DIRITTO INTERNAZIONALE 553-61 (2017). Cf. Regulation 2019/1155 of the European Parliament and of the Council of 20 June 2019 amending Regulation (EC) No 810/2009 establishing a Community Code on Visas (Visa Code), 2019 O.J. (L 188) 25, that entered into force on August, 1 2019, and will be applicable from February 2, 2020; while slightly simplifying the visa application processcounterbalancing with increased application fees-it integrates EU visa policy even more closely with the EU's external migration control policy. In fact, it provides for incentives and sanctions for non-EU countries which respectively cooperate or fail to cooperate on readmission. See Steve Peers, The revised EU visa code: controlling EU borders from a distance, EU $\mathrm{L}$. ANALYsis BlOG (Apr. 17, 2019), http://eulawanalysis.blogspot.com/2019/04/the-revised-eu-visa-code-controlling-eu.html (last visited Aug. 6, 2019). See also infra, note 31. 
are different from persecution as intended in the Convention, but also, for example, as a consequence of restrictive policies introduced by the shelter State. A similar situation has occurred in Lebanon - a State that is not a party to the Convention-in 2015, when the government asked to "de-register" the refugees that arrived in the country after January 5, 2015 and suspend new registrations. $^{21}$

Compared to similar practices, the Italian Memoranda expand the categories of the hypothetically vulnerable beneficiaries. With reference to this concept, however, it is possible to find some differences between the two agreements.

The first Memorandum provides for an extension of the protection to two different groups of people. First, those persons for whom "there are reasonable grounds to believe that, in case of return to their countries of origin, they would suffer significant damage also as a consequence of a situation of armed conflict, endemic violence or systemic violation of human rights" (common Article 3, litt. b). This provision recalls and combines the definitions of beneficiaries of subsidiary and temporary protection laid down in the EU legislation, respectively, in the "Qualification" and "Temporary Protection" Directives. ${ }^{22}$ The second group that may get an extension are those who, even where not included in the abovementioned categories, "lie in a situation of particular vulnerability for their personal situation, age or health conditions" including, inter alia, "single women with children, women victims of human trafficking, unaccompanied minors, elderly people," disabled or traumatized persons, and people with serious medical needs (Article 3, litt. c).

Conversely, the second and third Memoranda provide for the extension to other categories of migrants not otherwise covered by the Geneva Convention. Differently from the first MoU, the second and the third generically deal with all those persons finding themselves in conditions of serious "vulnerability determined by their personal situation, age or state of health," without any indication — not even by way of illustration-on the causes determining those conditions or on the specific underprivileged categories (Article 3, litt. b).

Notwithstanding these differences that may further expand the subjective scope of application of the second and third Memorandum and that may make the selection by the sponsor even more flexible, all the Memoranda specify that the identification of the beneficiaries has to take into account "in a complementary yet not substitutive manner" additional factors. In doing so, it is possible to include in the program persons who can benefit in Italy from the hospitality offered-formally, by individuals, churches, or associations that provide for the conditions for their first reception (Article 3, litt. $d$ ) -and/or who have relatives or social communities able

\footnotetext{
${ }^{21}$ See Vulnerability Assessment of Syrian Refugees in Lebanon 2016, UNITED NATIONS CHILDREN's FUND \& UNITED Nations High Commissioner for Refugees \& the United Nations World Food Programme, para. 13 (Dec. 16, 2016), http://documents.wfp.org/stellent/groups/public/documents/ena/wfp289533.pdf (last visited Aug. 6, 2019).

${ }^{22}$ See respectively, with regards to the beneficiaries of subsidiary protection, Art. 15, litt. $c$ of Directive 2011/95/EU, recasting Directive 2004/83/EC of 13 December 2011 on minimum standards for the qualification and status of third country nationals or stateless persons as refugees or as persons who otherwise need international protection and the content of the protection granted (recast), 2011 O.J. (L 337) 9. Vice-versa, as for the wider subjective scope of Directive 2001/55/EC of the Council of 20 July 2001 on minimum standards for giving temporary protection in the event of a mass influx of displaced persons and on measures promoting a balance of efforts between Member States in receiving such persons and bearing the consequences thereof (2001 O.J. (L 212) 12), see in particular its Art. 2, litt. c. There is a partial overlapping of the categories protected through the two acts but, in this moment the second Directive has not yet been "activated," lacking the requiredqualified-majority within the Council to approve the proposal by the Commission on the "establishment" of the same prerequisite of the "existence of a mass influx of displaced persons" (Art. 5.1), notwithstanding the requests made by the most interested Member States. See Guy S. Goodwin-Gill \& Jane McAdam, The Refugee in InTernational LaW 371-80, 325-34, 340-42 (3d ed. 2007); Steve Peers et al., Temporary Protection, in EU ImMigration and Asylum Law, supra note 17, at 571-615; Francesco Munari, Lo status di rifugiato e di richiedente protezione temporanea. La visione Europea del "diritto di Ginevra", in LE GARANZIE FONDAMENTALI DELL'IMMigRAZIONE IN EUROPA 48-54, 60-61 (Stefano Amadeo \& Fabio Spitaleri eds., 2015); AdELE Del GUERCIO, LA PROTEZIONE DEI RICHIEDENTI ASILO NEL DIRITTO INTERNAZIONALE ED EUROPEO 297-401 (2016); Francesco Cherubini, L'asilo dalla ConvenZione di Ginevra al diritTo dell'Unione Europea 216-23 (2012).
} 
to host them in Italy, and for this reason who have declared the will to establish and integrate themselves in the country (Article 3, litt. e). The ultimate aim of this provision is to "facilitate the identification of pathways to integration and to exclude secondary voluntary movement" (Article 3, last para. of all MoUs). ${ }^{23}$

As a consequence, the peculiar nature of humanitarian corridors as a Protected Entry Procedure stands out. They represent, indeed, a laudable initiative by private associations with recognized expertise in the field to provide for an alternative, legal, and safe pathway for single and well-identified individuals - not for multitudes or groups, such as in the case of resettlement. The sponsors select the beneficiaries of protection directly, with no delegation to other departments or international organizations. In addition, those procedures attribute a special relevance to the own will of refugees and migrants-as expressed well before the departure and directly shared with the promoting and "future hosts"- to be steadily and permanently integrated in the country where they will present their request for protection. Another aim is the exclusion of secondary and voluntary movements from the country of reception where pathways of integration already exist or where there are members of the family or other hosted communities with a lasting presence on the territory, or both.

The sui generis nature of the project is evident, not only because it represents an uncommon "model of public mobilization of the civil society in synergy with the State," 24 but also because it is rather different from any other protected entry procedures. ${ }^{25}$

\section{The Compatibility of the Model with Article 25 of the Visa Code After the $X$ and $X$ v. Belgium Judgment}

Almost three-and-a-half years since the conclusion of the first Memorandum, it is possible to define it as a success story. More than 2,000 persons in need of protection arrived in Italy through safe flights and have been hosted by the participating communities - which have worked on the integration of the beneficiaries - for the most part represented by families with children and persons needing medical care. Even though it is probably too early to predict the overall outcomes, as of today, the project has been functioning according to its initial objectives. Both the legal and safe arrival - on the one hand - and the first inclusion in communities spread all over Italy instead of in confined and isolated areas_-on the other hand-have been realized, even if on a small scale. Against this background, the aim of this study, as already mentioned, is to verify, first, if the model may be exported on a larger scale in other EU States and, second, if the paradigm needs to be adapted to reach this goal.

With regard to the first issue, the Italian best practice has already spread to France. On March 14, 2017, the Ministries of Foreign and Internal Affairs, on the institutional side, and the Community of Sant'Egidio, working as a promoter, the Fédération protestante de France, the Fédération de l'Entraide protestante, the Conférence des évêques de France et le Secours catholique-Caritas, on the ecumenical side, have signed a Memorandum. This agreement brings to France and French Territories Syrian and Iraqi families who have fled to Lebanon; the program had more than 360 arrivals in the span of eighteen months. ${ }^{26}$ Other Member States-namely, Germany

\footnotetext{
${ }^{23}$ Emphasis added.

${ }^{24}$ See Morozzo della Rocca, supra note 7, at 10.

${ }^{25} I d$. at $14-18$, for a detailed comparison with other protected entry procedures. At the same time, as PEPs, this pilot project differs from resettlement. In fact, as clearly indicated by NOLL \& FRAGERLUND, supra note 6, at 3:

What distinguishes Protected Entry Procedures from traditional resettlement is precisely the fact that the individual is directly engaging the potential host State in a procedure aiming at the securing of physical transfer and legal protection. In this mechanism, the individual autonomy of the protection seeker is accorded a central role.

${ }^{26}$ In implementing the project called "Opération d'accueil solidaire de réfugiés en provenance du Liban (couloirs humanitaires)," the first beneficiaries have arrived in France on July 15, 2017 and, by the end of June 2019, more than 360 welcomed persons arrived to France. Fédération Entraide Protestante, http://www.fep.asso.fr (last visited Aug. 6, 2019); CORRIDOI
} 
and Spain-have also devoted their attention to the project. Finally, Belgium, Andorra, the Holy Seat and the Republic of San Marino also have hosted some Syrian families, while the Polish Bishops' Conference has manifested its interest in participating. ${ }^{27}$

With the second issue-regarding the possibility to adjust the model for a uniform European format-it seems doubtful that the Memoranda will be appropriate to maintain its actual legal basis, Article 25 Visa Code, after the interpretation given to this provision by Court of Justice of the European Union ("CJEU") in March 2017 in the aforementioned case $X$ and $X v$. Belgium. In this case, the judges excluded its application to a situation potentially falling within the scope of the Italian Memoranda that was explicitly based exactly on that provision of the Visa Code.

In fact, the judges in Luxembourg in the abovementioned decision have established that a Member State - in the case at hand, Belgium - may refuse, without even providing for a justification, a request for an LTV visa presented for humanitarian reasons. In $X$ and $X v$. Belgium, a request for an LTV visa to the Belgian diplomatic premise in Lebanon by a family —including three minors - of Syrian Orthodox-Christian refugees subject to persecution in Aleppo was denied. The denial was based on the statement added to the visa application form that further international protection was intended to be requested once the family had arrived in Belgium.

In fact, according to the CJEU, a similar request would imply the family's will to remain on the Belgian territory well over the ninety days permitted by the Visa Code. Consequently, not only the Code itself, but also European Union law would be inapplicable, not to mention the standards of protection provided for in the Charter of Fundamental Rights ("the Charter"), particularly in

UMANITARI IN EUROPA (June 27, 2019), https://www.santegidio.org//downloads/Dossier-Corridoi-Umanitari-20190627-web. pdf (same). In order to better assess and evaluate the project and its impact on welcomed persons and host groups as well as to address the gaps and propose improvements, the project partners agreed to conduct a survey. This first survey has been shared with respondents at least three months after the arrival and the results have just been published in June 2019 (Digest_Couloirs_humanitaires_En.pdf, last visited Aug., 6, 2019). After having analyzed the main critical points, it contains recommendations providing a list of concrete measures aiming to improve the project design and fine-tune its implementation. Among these recommendations are these suggestions: (1) Provide comprehensive pre-departure information and postarrival assistance; (2) incorporate in the project space for intercultural dialog and exchange of experience; and (3) ensure access to qualified services provided by administrators and social workers at the local level. The duration of procedures as stated in the Agreement should be therefore respected to facilitate planning for the host groups and project partners. In cases where the deadlines cannot be respected, the State authorities should provide alternative solution and ensure commitment towards hosting the welcomed persons including access to financial allowance for asylum seekers-in France this has been restricted recently. Another priority is to guarantee quick access to free psychosocial support and, in some cases, where arriving persons have strong disabilities that require specific type of accommodation-for example persons in a wheelchairit is suggested that the State should guarantee a priority access to adapted public facilities where a host group can provide the socio-cultural and emotional support. Finally, in order to facilitate integration, it is strongly recommended to guarantee for all asylum seekers access to the job market and to French courses from the moment the asylum claim registration occurs-not once the protection is granted-and to provide information and support on family reunification procedures with their closest relatives and family members who stayed behind in Syria, Lebanon, or Iraq.

${ }^{27}$ See Sossai, supra note 7, at 89; report released on June 27, 2019, by the Community of Sant'Egidio, indicating around 150 Syrian nationals from Lebanon and Turkey joining Belgium by December 2018, and another seven in Andorra by October 2018, Corridoi umanitari in Europa, supra note 8, at 7. With specific regard to the Belgian protocol, it was signed on 22 November 2017 by the Government of Belgium, the Community of Sant'Egidio — with the role of coordinator-and the local Churches, with the support of the Jewish and Muslim communities. These numbers bring the total beneficiaries welcomed in Europe to 2,669, as for the data collected by June 2019. See also Humanitarian Corridors: implementation procedures for their extension on a European scale, prepared by the members of the Working Group of the "Humanitarian Corridors Project. Upscale a promising practice for clearly linked pre-departure and post-arrival support of resettled people-sponsored by the Asylum, Migration and Integration Fund of the European Union (AMIF/2016/AG/INTE)", drafted thanks to the following: Apg23 (Associazione Comunità Papa Giovanni XXIII, Pope John XXIII Community Association); Italian Community of Sant'Egidio; French Community of Sant'Egidio; Salesiani per il Sociale (Salesian association for social advancement); CNOSFAP National Federation (Centro Nazionale Opere Salesiane/Formazione Aggiornamento Professionale, National Centre of Salesian Works/Professional Training); VIS (Volontariato Internazionale per lo Sviluppo, International Volunteering Association for Development), at https://www.humanitariancorridor.org/wp-content/uploads/2019/12/REPORT_ENG_WEB. pdf (last visited Dec. 4, 2019). 
Articles 4 and 18, respectively recognizing the prohibition of torture and inhuman and degrading treatments, as well as the right to asylum.

Even if the motives underpinning the application for an LTV do not determine the applicability of the Visa Code per se, the CJEU comes to this-indeed questionable-conclusion following a rather intricate and non-linear reasoning. The express intention to formally request international protection incorporated in an LTV application is interpreted as inapplicable to the Visa Code, but not as a possible reason of rejection of the same application, pursuant to Article 32(1) $b$, as argued by the Advocate General. According to the judges in Luxembourg, the request should be re-qualified as a long-term visa because of the disclosed intention to ask for international protection once arrived in Belgium, and therefore to remain for longer than ninety days. Based on these assumptions, and considering that the competence in the field of defining uniform criteria for the issuance of a visa or long-term residence permits provided for in Article 79 (2) $a$ of the Treaty on the Functioning of the European Union ("TFEU”) has not yet been exercised by the Union, the Court finds that the competence still falls within the Member States' discretion, leaving them free to grant or refuse the visa. ${ }^{28}$

The CJEU thus affirms the inapplicability of EU law with reference to temporary visas for humanitarian reasons and therefore the unfeasibility to base on EU law and, particularly, on Articles 4 and 18 of the Charter, the obligation for a Member State to grant a LTV to persons that, in case of refusal, would find themselves exposed to a clear danger of persecution on the basis of religious beliefs or inhumane and degrading treatment in a third country.

This is an inadmissible outcome that openly contradicts the objectives of the Visa Code, which according to its preamble are "aimed at facilitating legitimate travel and tackling illegal immigration through further harmonization of national legislation and handling practices at local consular missions" (recital no 3), and at respecting "fundamental rights and observes the principles recognized in particular by the Council of Europe's Convention for the Protection of Human Rights and Fundamental Freedoms and by the Charter of Fundamental Rights of the European Union" (recital no 29). Such interpretation seems to run counter to the previous extensive and significant jurisprudence of the Court in Luxembourg on the interpretative canons to be followed in the exegesis of secondary Union law; ${ }^{29}$ it also contradicts the 1969 Vienna Convention on the Law of Treaties (Articles 31-32).

It is highly disappointing that in the analyzed judgment, the Court has moved away from the long and passionate opinion rendered by the Advocate General Mengozzi, who stood for the application of Article 25 of the Visa Code and of the Charter of Fundamental Rights. In moving away from the previous positions, the CJEU has deluded expectations for a courageous and consistent stance, that the Union did not uphold, on the prevalence of the human rights of migrants in conditions of extreme vulnerability and in urgent need of protection over the opposing security and protectionist approaches maintained by the States.

The real reasons hindering the application by the CJEU of Article 25 of the Visa Code seem concealed in the final paragraphs of the judgment rendered by the Court. ${ }^{30}$ Both the judges in Luxembourg and the Member States were concerned that diplomatic representations of Member States in third countries would have been immediately inundated by an overflow of requests of LTVs, and they would not have been prepared for that. In addition, the Court did not want to favor the phenomenon of so-called asylum shopping-for example, the possibility for potential beneficiaries of protection to pick and choose the Member State from which they would request international protection. An opposite decision, the CJEU admits, would have

\footnotetext{
${ }^{28}$ See Case C-638/16 PPU, État belge, at paras. 43-44, 46-47.

${ }^{29}$ See supra note 20: the opinion of Advocate General Mengozzi, at paras. 6, 103; Violeta Moreno-Lax, Asylum Visa as an Obligation under EU Law, part I-II; Del Guercio, at 291.

${ }^{30}$ See Case C-638/16 PPU, État belge, at paras. $48-49$.
} 
probably caused the collapse of the — already shaky_-Dublin system that Member States are stubbornly conforming to.

Against this background, the process of amending the Visa Code, which started in 2014 after a troubled evolution with different deadlocks and policy re-definition, has registered an acceleration in the first months of 2019. The resulting Regulation (EU) 2019/1155, approved by the Parliament and the Council on June 26, 2019, brings together visa policy and re-admission cooperation with third countries but does not contain any specific provision on the duty to grant humanitarian visas to people fleeing from persecution and torture that ask protection of the diplomatic premises of the Member States abroad, as the European Parliament proposed to the Commission. ${ }^{31}$ The new framework instead establishes stricter conditions for processing visas in cases where a third country does not cooperate satisfactorily on readmission. In fact, some provisions-such as those related to the visa fees, the time taken to issue decisions on applications, and the length of time for which multiple entry visas are valid - may be adapted depending on whether a given non-EU country cooperates "sufficiently," or alternatively "insufficiently," on readmitting irregular migrants, following a "full and objective assessment" carried out by the European Commission every year. With specific reference to Article 25, the only effect generated by this new approach consists of the introduction of Article 25(a), on the basis of which States could be authorized to restrict the granting of an LTV to asylum seekers or people in need of international protection even more. In fact, where there is a lack of cooperation by certain third countries to re-admit those of their nationals who have been apprehended in an "irregular situation," and where there is a failure by those third countries to cooperate effectively in the return process, a restrictive and temporary application of Article 25-including paragraph 1 -is applied. It is a sort of EU unilateral system of incentives and sanctions at the same time to enhance third countries' cooperation on re-admission of irregular migrants. Such a scheme, which unfortunately appears more

\footnotetext{
${ }^{31}$ In 2014 the Commission proposed a recast of the Visa Code [COM(2014) 164 fin., 1 Apr., 2014], mainly to further facilitate legitimate travelers - tourists, students, businessmen — and enhance economic growth through the simplification of rules for EU citizens and their non-EU family members. EP strongly insisted including humanitarian visa in the proposal, but no agreement could be reached on its amendments due to the diverging positions taken by the Commission and the Council on the ground, among others, that provisions on those kind of entry permit should not be included in the Visa Code "given that its scope covers short-stay visas only," see the interinstitutional file no. 2014/0094 (COD), 14 Nov., 2016, published at http:// www.statewatch.org/news/2016/nov/eu-council-code-visas-14213-16.pdf (last visited Aug. 6, 2019); and for the complex legislative train, http://www.europarl.europa.eu/legislative-train/theme-towards-a-new-policy-on-migration/file-humanitarianvisas-amendment-of-the-eu-visa-code (last visited Aug. 6, 2019). Some months after the CJEU judgment commented in the text, in September 2017, following the deadlock in trilogue negotiations, due to the Commission and Council's continuous opposition to include provisions for a humanitarian visa, Parliament withdrew its amendments. Nonetheless, following the inactivity of both institutions, the Parliament passed a non-binding Resolution [P8_TA(2018)0494] on Humanitarian Visas with recommendations to the Commission [2018/2271(INL), 11 Dec., 2018], proposing a separate legal act to be adopted in the form of an ad hoc regulation establishing a European Humanitarian Visa, its legal basis being point (a) of Art. 77(2) TFEU, introducing an "automatic link between the admissibility declaration and the need to issue an LTV." The Resolution was based on a detailed study on the issue

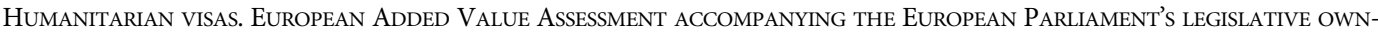
INITIATIVE REPORT. STUDY FOR THE EP (Wouter van Ballegooij and Cecilia Navarra, PE 621.823 Oct. 2018) and spec. the chapter by Violeta Moreno-Lax, The Added-Value of EU Legislation on Humanitarian Visas-Legal Aspects, 90-98. The legislative initiative report was backed by $429 \mathrm{MEPs}$ - 194 voted against and 41 abstained - but the Council and the Commission have still been arguing that the Visa Code's aim is not to deal with migration, and that the issue should be examined within the EU Resettlement Framework. In the meantime, the increased security and migratory challenges rendered some aspects of the first recast proposal out of the new focus, more centered on addressing security issues and contrasts to irregular migration. The Commission therefore decided to withdraw the first recast proposal and presented a new targeted one, following the approach supported by the Council of linking visa policy to repatriation by third States, but without tackling the issue of humanitarian corridors in the same act, see EUR. PARL. Doc. (COM 251 fin.) (2018)., and particularly for the overall objective of the proposal amending the Visa Code point 3.1). Finally, Regulation (EU) 2019/1155 amending Regulation (EC) No 810/2009 establishing a Community Code on Visas (Visa Code) was adopted by the European Parliament and the Council on June 20, 2019, 2019 O.J. (L 188) 25. For further details on contents and the legislative train of the revision of the Visa Code, see supra note 20; Legislative Train Schedule, EUROPEAN PARLIAMENT, http:// www.europarl.europa.eu/legislative-train/theme-towards-a-new-policy-on-migration/file-revision-of-the-common-visa-code (last visited Aug. 6, 2019).
} 
politically oriented than human rights based, will most probably become a bounce back primarily for the vulnerable people fleeing persecutions from those same countries that are not cooperative at all.

Although the legal community is waiting for a specific future act dedicated to alternative legal pathways including humanitarian visas, at present, Article 25 remains the only EU rule that admits the possibility of granting a visa "when the Member State concerned considers it necessary on humanitarian grounds, for reasons of national interest or because of international obligations." Within the legal framework applicable from 2020, two specific points of the amended Visa Code timidly suggest a possible positive future reading of the provision. In particular, an explicit reference to the duty of the States to act in full compliance with the Charter when applying such an act has been introduced to Article 1 at paragraph 4; moreover, in case of a declaration of refusal of the LTV, paragraph 2 of Article 32 has been replaced in order to grant both the notification of the exact reasons on which such a decision was rendered and an effective appeal.

Nonetheless, the unclear stance of the EU legislators towards humanitarian safe ways in redefining the content of Article 25 of the Visa Code, as well as the legal nationalism in the backdrop of the analyzed CJEU interpretation thereof, both suggest to avoid maintaining at present the reference to such provisions in the Italian MoU. This suggestion comes especially because of the essential role played in these agreements by the express will of the beneficiary to indefinitely settle and remain in the territory of the issuing State to apply for international protection. ${ }^{32}$ In this vein, it is indicative that the MoU concluded in France some days after the judgment rendered by the Court of Justice does not mention Article 25 of the Visa Code as its legal foundation, even if there is no specific legal framework mentioned either.

\section{E. International Law as the Proper Legal Basis}

The substantial concern with embracing the CJEU interpretation is that humanitarian visas should not be a matter of discretion for the States once the conditions exist to grant temporary protection from serious risk of persecution, torture, or cruel and inhuman treatments, if not of death. The legal basis for imposing the obligation on any State to grant a visa in said conditions is already provided for by international law, both general and conventional. The Court in Luxembourg should have affirmed the duty of the Belgian authority to grant an LTV visa "by virtue of international obligations" recalled in the same Article 25 of the Visa Code. Instead, it did not even decide on the specific issue, punctually raised by the referring judge.

More precisely, pursuant to such obligations, it should have been an affirmed duty for a EU Member State to grant an LTV visa requested to the consular representation abroad-Lebanonby the Christian Orthodox Syrian family, which included underage children, that was being persecuted due to their religious beliefs in Syria. This is true especially when considering that the refusal of such a permit might have led to a real risk of irreparable harm, either in the country to which the applicants found refuge or in any country to which the persons may subsequently be expelled.

In particular, reference should have to be made unquestionably to the principle of nonrefoulement-and, therefore, in primis, to Articles 31 and 33 of the 1951 Geneva Convention. Despite practices of "obstructing asylum"33 followed by many States and aimed at factually impeding the access on the territory to exclude ex ante the possibility of requesting international protection, some authors have held that the prohibition of non-refoulement shall conversely imply

\footnotetext{
${ }^{32}$ It is nevertheless true that CJEU decision shall not imply the prohibition for Member States to conclude agreements with private sponsors for the opening of humanitarian corridors. Cf. Del Guercio, supra note 20, at 287-88. See Pasquale De Sena, Still Three Different Status for Aliens, Citizens and Human Persons?, in Global Justice, Human Rights and THE Modernization of InTERnAtional LAW, supra note 4, 239ss., spec. para. 3.2, 249-51.

${ }^{33}$ GoOdWIN-Gill \& McAdAM, supra note 22 , at 371-80.
} 
an obligation of admission and temporary stay. ${ }^{34}$ Admission and temporary stay have to be intended as instrumental to the protection of the applicant until the State has verified for each request the alleged circumstances as ensured by the Convention or, as long as the State has ascertained that the person would not be exposed "in any manner whatsoever" to the risk of persecution, in the country towards which the person in question would be refoulet.

This extensive interpretation of the principle of non-refoulement-and its extraterritorial effect-is strongly supported by different general rules of international law, such as customs and principles, as well as by treaty provisions on human rights. ${ }^{35}$ Reference is made to the right to life, as codified in Article 6 of the 1966 Covenant on Civil and Political Rights, ${ }^{36}$ which, in its subsequent Article 7, provides for the prohibition of torture and other cruel, inhumane, or degrading treatment, as already mentioned.

With regard to the first provision, in the recent General Comment No. 36, the Human Rights Committee expressly specifies that "the duty to protect the right to life requires the Member States to take special measures towards persons in situation of vulnerability ... [such as] unaccompanied migrant minors ... asylum seekers, refugee." 37 The Committee upholds a broad interpretation of "the obligation not to extradite, deport or otherwise transfer pursuant to Article 6 of the Covenant," postulating that it "may be broader than the scope of the principle of non-refoulement under international refugee law, since it may also require the protection of aliens not entitled to refugee status."

With specific reference to the interconnected prohibition of torture, it has become a rule of such a fundamental character for the entire international community to be afforded an absolute, imperative, and non-derogable nature, binding upon all States, including those who did not ratify the 1984 Convention on the Prohibition of Torture and Cruel, Inhuman or Degrading Treatments

\footnotetext{
${ }^{34}$ In this sense, see James C. Hathaway, The Rights of RefugeEs under InTERnATIONAL LAW 278-302 (2005); similarly, Nils Coleman, Non-Refoulement Revised. Renewed Review of the Status of Non-Refoulement as Customary International Law, 5 Eur. J. Migration \& L. 23-68, particularly 40 ff. (2003); Elihu Lauterpracht \& Daniel Bethlehem, The scope and content of non-refoulement: Opinion, in Refugee Protection in International Law. UnHCR's Global Consultations on International Protection 113-17 (Erika Feller et al. eds., 2003); Goodwin-Gill \& McAdam, supra note 22, at 206-08, 211-13, 290; FEDERICO LENZERINI, AsILO E DIRITTI UMANI: L'EVOLUZIONE DEL DIRITTO D’ASILO NEL DIRITTO internazionale 404-14 (2009); Agnès Hurwitz, The Collective Responsibility of States to Protect Refugees 176 (2009); Cornelius W. Wouters, International Legal Standards for the Protection from Refoulement: a Legal Analysis of the Prohibitions of Refoulement Contained in the Refugee Convention, the European Convention of Human Rights, the International Covenant on Civil and Political Rights and the CONVEntion against TORTure 148-51, 569-70 (2009); Cherubini, supra note 22, at 43-48; Hélène Lambert, Temporary Refuge from War: Customary International Law and the Syrian Conflict, 66 INT'L \& CoMP. L.Q. 723-45, spec. 727 (2017); Violeta Moreno-Lax, Accessing Asylum in Europe. Extraterritorial Border Controls and Refugee Rights under EU LAW, 247-335 (2017).

${ }^{35}$ See Paolo Benvenuti, La Convenzione di Ginevra sullo status dei rifugiati, in LA TUTELA INTERNAZIONALE DEI DIRITTI UMANI 207 (Laura Pineschi ed., 2006); Wouters, supra note 34, at 359-520; Francesco Salerno, L'obbligo internazionale di non-refoulement dei richiedenti asilo, in ProcedURE E GARANZIE DEL DIRITTO DI ASILO 3 (Chiara Favilli ed., 2011); DEL GuerCiO, supra note 22 at 54-111; Lauterpach \& Bethlhem, supra note 34, at 155-64.

${ }^{36}$ Dinah L. Shelton, Advanced Introduction to International Human Rights Law, 74-80, 149-55 (2014). On the expansion of the notion of jurisdiction of State Parties to the Covenant on Civil and Political Rights and the ECHR, see generally Pasquale De Sena, La nozione di giURisdizione statale nei tratTati sui diritTi dell'UOmo (2002).

${ }^{37}$ Human Rights Committee, General Comment No. 36 (2018) on article 6 of the International Covenant on Civil and Political Rights, on the right to life, CCPR/C/GC/36 (Oct. 8 to Nov. 2, 2018), paras. 23, 31. This wider protection is extraterritorial in nature as specified in the passport cases, where the Committee affirmed the jurisdiction of the respondent States on the basis of Art. 2(1) of the Covenant on Civil and Political Rights and Art. 1 of the Protocol, see, among others, HRCtee, Varela Núñez v. Uruguay, Communication no 108/1981 (July 22, 1983), UN Doc. CCPR/C/19/D/108/1981, paras. 6.1s.; Lichtensztejn v. Uruguay, Communication no. 77/1980 (Mar. 31, 1983), UN Doc. CCPR/C/OP/2, para. 6.1; Vidal Martins v. Uruguay, Communication no. 57/1979 (Mar. 23, 1983), UN Doc. CCPR/C/15/D/57/1979, para. 7. Cf. De Sena, supra note 32, at 251 .
} 
or Punishment ("CAT"). ${ }^{38}$ The same Convention includes the refoulement within the conducts expressly prohibited in Article 3, to which the new General Comment No. 4 adopted by the CAT Committee has been devoted. General Comment No. 4 confirms that the principle of non-refoulement "is similarly absolute" and must be applied by any State party "in any territory under its jurisdiction or any area under its control and authority" to citizens or non-citizens "without discrimination subject to the de jure or de facto control," as established by the so-called passport cases decided by the Committee interpreting the same concept of jurisdiction under the Covenant on Civil and Political Rights. ${ }^{39}$

The same principle is recalled by the European Convention on Human Rights ("ECHR") as interpreted and applied under the lens of a large body of case-law of the Court in Strasbourg, ${ }^{40}$ primarily relating to the prohibition of torture and inhumane and degrading treatments, and to its extra-territorial effects as enshrined in Article 3-and affirmed clearly in the Hirsi case ${ }^{41}$ —as well as in Article 4 of Protocol No. 4 to the ECHR, expressly devoted to the principle of non-refoulement. Under the ECHR system, conventional standards are applicable to those individuals that are subject to the jurisdiction of the State Party-for example, to those who are under its direct and effective control. ${ }^{42}$ Subjection to such a kind of control has been referred by

\footnotetext{
${ }^{38}$ In the judgment on Questions relating to the Obligation to Prosecute or Extradite (Belg. v. Sen.), Judgement, 2012 I.C.J. 422 para. 99 (July 20), the International Court of Justice held that:

... the prohibition of torture is part of customary international law and it has become a peremptory norm (jus cogens). That prohibition is grounded in a widespread international practice and on the opinio juris of States. It appears in numerous international instruments of universal application (in particular the Universal Declaration of Human Rights of 1948, the 1949 Geneva Conventions for the protection of war victims; the International Covenant on Civil and Political Rights of 1966; General Assembly Resolution $3452 / 30$ of 9 December 1975 on the Protection of All Persons from Being Subjected to Torture and Other Cruel, Inhuman or Degrading Treatment or Punishment), and it has been introduced into the domestic law of almost all States; finally, acts of torture are regularly denounced within national and international fora.
}

See ex multis Dominique Carreau \& Fabrizio Marrella, Diritto internaZionale 74-88 spec. at 76-77 (2d ed. 2018); Benedetto Conforti, Diritto internazionale (Massimo Iovane ed., 11th ed. 2018); Antonio Cassese, Diritto INTERNAZIONALE 253-55 (Micaela Frulli ed., 3d ed. 2017); Tullio Scovazzi, Le norme generali e le altre categorie di norme, in Corso di Diritto internazionale. Parte II (Tullio Scovazzi ed., 2d ed. 2015); Jochen A. Frowein, Ius Cogens, in Max Planck Encycolpedia of Public International LaW (2013); Tullio Scovazzi \& Gabriella Citroni, La tutela internazionale dei diritti umani, in Corso Di DIRITTO INTERNAZIONALE. PARTE III, 126-44, 219-22, 324-40 (Tullio Scovazzi ed., 2013).

${ }^{39}$ Committee Against Torture, General Comment No. 4 (2017) on the implementation of article 3 of the Convention in the context of article 22, U.N. Doc. CAT-C-GC-4 (Feb. 9, 2018), paras. 9-10, recalling previous CAT communications No. 39/1996, Tapia Paez v. Sweden, views adopted on 28 April 1997, para. 14.5; No. 110/1998, Núñez Chipana v. Venezuela, views adopted on 10 November 1998, para. 5.6; No. 233/2003, Agiza v. Sweden, decision adopted on 20 May 2005, para. 13.8; No. 297/2006, Singh Sogi v. Canada, decision adopted on 16 November 2007, para. 10.2; No. 444/2010, Abdussamatov et al. v. Kazakhstan, decision adopted on 1 June 2012, para. 13.7; and No. 475/2011, Nasirov v. Kazakhstan, decision adopted on 14 May 2014, para. 11.6. See for a comment Flavia Zorzi Giustiniani, Divieto di non-refoulement e tortura. Osservazioni in margine al General Comment n. 4 alla Convenzione ONU contro la tortura e altre pene o trattamenti crudeli, inumani o degradanti, 2 Federalismi.it - Focus on Human Rights (2018). For the passports cases, see supra note 37.

${ }^{40}$ Moreno-LaX, supra note 34, at 266-80; Alessandra Lang, Il divieto di refoulement tra CEDU e Carta dei diritti fondamentali dell'Unione europea, in LE GARANZIE FONDAMENTALI DELL'IMMIGRATO IN EUROPA 209-44 (Stefano Amadeo \& Fabio Spitaleri eds., 2015); DEL GUERCIO, LA PROTEZIONE DEI RICHIEDENTI ASILO, supra note 22 at 120-226.

${ }^{41}$ ECHR, Hirsi Jamaa et al. v. Italy, App. No. 27765/09 (Feb. 23, 2012) and the first comments by Claudio Zanghì, L'intervento in alto mare tra "non refoulement," diritti umani e contrasto all'immigrazione clandestina, in SCRITTI IN ONORE DI UGO DRAETTA 815 (Nicoletta Parisi et al. eds., 2011); Alessandra Gianelli, Respingimenti di stranieri indesiderati verso la Libia e Convenzione europea dei diritti dell'uomo, GIUR. Cost. 2358 (2012); Federico Lenzerini, Il principio del non-refoulement dopo la sentenza Hirsi della Corte europea dei diritti dell'uomo, RIV. DIR. INT. 712 (2012); Nicola Napoletano, La condanna dei 'respingimenti' operati dall'Italia verso la Libia da parte della Corte Europea dei diritti umani: molte luci e qualche ombra, DIRITTI UMANI E DIRITTO INTERNAZIONALE 227 (2012); Mariagiulia Giuffrè, Watered-down Rights on the High Seas: Hirsi Jamaa and Others v. Italy, 61 INT'L \& CoMP. L.Q. 728-50 (2012).

${ }^{42}$ Marko Milanovic, Jurisdiction and Responsibility. Trends in the Jurisprudence of the Strasbourg Court, in THE EUROPEAN Convention on Human Rights and General International Law (Anne van Aaken and Iulia Motoc eds., 2018). 
the European Commission of Human Rights ${ }^{43}$ and the European Court in Strasbourg to actions performed by diplomatic and consular representatives abroad, as in Assanidze, where it was affirmed that "in certain exceptional cases, jurisdiction is assumed on the basis of non-territorial factors such as the activities performed by diplomatic and consular representatives of State." 44

Other important obligations for the States relate to: The right of respect for the family life and the principle of the best interest of the child-upon which the 1989 New York Convention has been built; ${ }^{45}$ and the right of any individual to an effective remedy, which represents a basic principle-nonetheless violated by the Belgian State when refusing the visa request in the aforementioned case-recognized at different levels, not only regionally-as the Charter and the ECHR — but also globally — in different international law instruments — and locally_domestic legal orders of the States. ${ }^{46}$

All the above-mentioned principles and provisions could have justified the necessity to grant an LTV under Article 25 Visa Code in the context of $X$ and $X v$. Belgium. Even if there has been no dictum by the CJEU on the specific issue, the margin of discretion by Member States cannot be exercised in any way without respect for the limits posed by obligations arising from international law. By holding to a formalistic interpretation of European law without even considering the stronger duties derived from the international legal order, the judges in Luxembourg preferred to support an overly fragile reading, particularly if measured on the basis of "humanitarian values and of the respect of human rights on the basis of which the European construction is built ... as affirmed in Articles 2 and 3 of the Treaty on the European Union, respectively." ${ }^{\prime 7}$

\section{F. Open Issues for the Spread of a Virtuous Practice in Europe}

The Court in Luxembourg has certainly lost a chance to use an already existing normative tool in order to harmonize very fragmented national practices. At present, Member States govern the granting of visas for humanitarian reasons, whether for a short or long term, in a discretional and non-univocal way. ${ }^{48}$ These same practices, where well managed, would conversely ensure

\footnotetext{
${ }^{43}$ As for the European Commission of Human Rights, see X v. The Federal Republic of Germany, App. No 1611/62 (Sep. 25, 1965), in 8 YeArbook of ECHR, 157ss. (1965). See De Sena, supra note 32, at 250.

${ }^{44}$ ECHR, Assanidze v. Georgia, App. No. 71503/01, para. 137 (Apr. 8, 2004). In the same vein, see ECHR, Bankovic and Others v. Belgium and Others, App. No. 52207/99, para. 73 (Dec. 12, 2001). For analogous cases, where it was held that "there indisputably exists a 'jurisdictional link' for the purpose of Article 1 ECHR" in bringing a civil action to a court of a State, which just receives it and takes no other active steps, see ECHR, Markovic v. Italy, App. No. 1398/03, para. 12 (Oct. 20, 2005); Moreno-LaX, AcCessing Asylum In Europe, supra note 34, at 309-11 (quoting similarly, Haydaire v. The Netherlands, App. No 8876/04 (Oct. 20, 2005), a case of request for reunification of a family, where the Court upheld the existence of the jurisdiction of The Netherlands pursuant to Art. 1 ECHR over the three minor children living in Pakistan while the mother was residing in the requested State).

${ }^{45}$ See the Convention on the Rights of the Child, adopted and opened for signature, ratification and accession by General Assembly resolution 44/25 of 20 November 1989, arts. 7 et seq.; Cristina Campiglio, Disciplina delle migrazioni: limiti internazionali, in Il DiritTo Dell'immigrazione. Profili di DiritTo itAliano, Comunitario E INTERNAZIONALE. VOl. I 23-44, particularly 28-29 (Vittorio Gasparini Casari ed., 2010); DEL GUERCIO, LA PROTEZIONE DEI RICHIEDENTI ASILO, supra note 22, 113-18, also recalling relevant provisions in the 1990 Convention on the Protection of the Rights of All Migrant Workers and Members of their Families as well as the 2000 Protocol on trafficking annexed to the Palermo Convention.

${ }^{46} \mathrm{Cf}$. Carlier \& Leboef, supra note 20; for a recent decision on Article 32(3) of Regulation (EC) No 810/2009, read in the light of Article 47 of the Charter of Fundamental Rights of the European Union, confirming the obligation for Member States to guarantee the right to an effective judicial appeal against the refusal to grant an LTV, CJEU, Case C-403/16, El Hassani (Dec. 13, 2017), ECLI:EU:C:2017:960.

${ }^{47}$ See Case C-638/16 PPU, Etat belge, at para. 6. Moreover, the refusal of a visa for humanitarian reasons undoubtedly implies consequences for European common asylum policies and their implementation. This may lead us to consider the issue as falling within the competences of the European Union precisely owing to the jurisprudence developed by the Court in relation to the "effet utile," therefore causing the application of the Charter, and its Article 18, which would not be subordinated to State discretion. Cf. id. at paras. 49, 70, 76, 80, 88, 90, 97.

${ }^{48}$ Ibsen Jensen, supra note 19 , at $28-34$.
} 
the host State the remarkable advantage to monitor, and select, prior to the departure those subjects who have been already identified and registered by the public authority as granting greater chances to become fully integrated in their State. Precisely, a specific warranty comes from their explicit will to establish themselves in the national community-even before the selection process starts - and the further requirement of the already existing links with the host communities. Moreover, in some cases, together with the sponsors, the beneficiaries can prove the presence on the territory of already established members of their families, to whom they would nevertheless have the right to be reunited with, as a "corollary of the more general right to respect of familiar life." 49

Nevertheless, some questions are still open with regards to extending the scope of application of the already adopted MoU. Particularly, a first issue connected to the successful outcome of those virtuous projects is the identification of the States, be they transit or host States, that would be best suited to implement them.

Under a second perspective, the definition of the concretely applicable selection criteria and procedures should not be completely delegated to private parties, in case of generalized extensions of the project to a larger number of sponsors, who lack expertise, that may be interested in exploring the possibility of open humanitarian corridors. ${ }^{50}$

To reach this goal, both the States and non-State actors should start encouraging a new narrative on migrations through the diffusion and sharing of the successful methods currently used for integration. This would also allow a better harmonization of arrangements for the admission of refugees by pursuing their integration according to an "adoption-like" model, not intended as a direct intervention by the State, but rather as a "a whole-of-society" action supported by the guidance of public authorities. ${ }^{51}$ Such a guidance should be possibly established at different levels, both national and European, according to the paradigm of a "multi-stakeholder alliance" suggested in the Global Compact and supported by the General Assembly of the United Nations; far from diminishing the role of States as primary subjects and responsibility bearers under international law, the alternative and flexible solutions indicated by non-State actors would conversely require the States "to respect and enforce" human rights at national and regional level even more effectively. ${ }^{52}$ It would be, indeed, desirable to direct the recast of the relevant EU law, still under way, to this end, ${ }^{53}$ because "to be a credible alternative to illegal migration and the

\footnotetext{
${ }^{49}$ In this sense, see Campiglio, supra note 45 , at $28-29$.

${ }^{50}$ The first agreement, as an example, has been a driving force for the launch of a subsequent, unusual project called "Adottiamo il futuro" (Let's adopt the future) between FCEI and the Federazione nazionale lavoratori agroindustriali (FLAI-CGIL). This trade union, since May 1, 2017, has committed itself to implementing "mentoring support" for a year, and therefore also has to pay the expenses deriving from the reception of one of the families of Syrian refugees that arrived in Italy via the humanitarian corridors from Lebanon, see, FCEI http://www.nev.it.

${ }^{51}$ See Morozzo della Rocca, supra note 7, at 30 (recalling the effective definition laid down for humanitarian corridors by Impagliazzo, supra note 7, at 127 and by Andrea Riccardi, L'Europa dei migranti. Modelli di integrazione, in INTEGRAZIONE $103 \mathrm{ff}$. (Marco Impagliazzo ed., 2013)). A model of coexistence "inspired to the values of the Constitution" is at the basis of the Primo piano nazionale di integrazione, presented on September 27, 2017, at the Ministry of Internal Affairs. This Ministerial framework aims at striking a balance between the rights and duties of those who are received and of those who receive: The first commit themselves to learning the Italian language, sharing the values of the Italian Constitution, respecting the laws, and participating in the social, economic, and cultural life of the territory where they live, while the latter take the commitment to ensure equality of treatment and dignity, freedom of religion, access to education and training, as well as all those interventions aiming at facilitating the inclusion in the receiving society, respecting at the same time its non-negotiable values. See Ministero Dell'InTerno, http://www.interno.gov.it (last visited Aug. 6, 2019).

${ }^{52}$ See New York Declaration for Refugees and Migrant, supra note 1, at para. 15. Cf. on the role of non-State actors in re-shaping the same nature of international law, Decaux, supra note 4, at 15 (affirming also that "State must not resign from their first responsibility which is to respect and enforce international law, but it is at the national level that international law must find its effectiveness").

${ }^{53}$ Del Guercio, supra note 20, at 287-90; Ibsen Jensen, supra note 19, at 18-27, 36-37; Moreno-Lax, supra note 31, at 79-98. The European Parliament considers that an ad hoc legislative act should be adopted because of the
} 
territorial seeking of protection, Protected Entry Procedures must be utilized widely and function in a predictable and uniform manner," 54 as suggested by the Italian sponsors since the first MoU (point 7).

Humanitarian visas are clearly one of the tools that countries could use to enable people in need to access international protection legally and safely. There is currently no harmonization at the EU level of PEPs and no legal framework at the Union level for humanitarian visas for vulnerable people seeking international protection. Pending a structural reform, ${ }^{55}$ the involvement of the third sector may have a decisive role in solving the impasse that European governments and EU organs are currently unable to jointly overcome, even though single countries are showing a greater commitment. As such, humanitarian corridors represent a possibility within the wider framework of intermediary options between an unconditional opening and the closure of all channels for a regular entry. This peculiar pathway should be reinforced with the supporting role of the State: It is the subject that is primarily obliged to respect international law and protect fundamental human rights in order to provide for the right "environment that facilitate implementation of these responsibilities," while avoiding - on the one hand-impeding on civil society in order to fulfill their common obligations and-on the other hand-preventing the vulnerable migrants from accessing the protection rights that are already recognized at different normative levels. ${ }^{56}$

It is thus crucial to immediately start a serious and de-politicized reflection on the reopening of all the existing legal channels of entry-in order to rescue those who cannot wait until an

added value of Union action, in terms of ensuring compliance with Union values, including fundamental rights, mutual trust between Member States and confidence in the system by asylum seekers, legal certainty, foreseeability, and the uniform application and implementation of the rules, the achievement of economies of scale, and the reduction of the [below]-cited costs of the status quo.

$[\mathrm{T}]$ he high costs, in human but also in social, economic and budgetary terms, associated with the status quo for the third-country nationals concerned (smuggler fees, risk of trafficking and exploitation, risk of persecution, risk of death and ill treatment, etc.) and for Member States and the Union (elevated budget for search and rescue, including for private shipping, border protection, cooperation with third countries, asylum procedures and possibly return in case of rejected applications for international protection as well as the fight against organized crime, trafficking and smuggling etc.).

C.f. PE Resolution of Dec. 11, 2018 (P8_TA-PROV(2018)0494), supra note 31, at para. 3, fourth and third sub-indent.

${ }^{54}$ Noll \& FagerLund, supra note 6 , at 4.

${ }^{55}$ See supra note 31; as described, the debate among the three organs of the EU involved in the recast of the Visa Code has developed since 2014 and-with specific regard to the issue of humanitarian visa-the previous request by the European Parliament to introduce a provision thereon was followed by the firm criticism of the Commission and the Council. Subsequently, in December 2018, the Parliament advanced its own initiative through a resolution, cf. also supra note 53, aimed at the adoption of a specific EU instrument dedicated to the issue. In fact, after a complex legislative train, European Parliament agreed to deal with it separately from the Visa Code, whose recast negotiations have led in the meanwhile to Regulation (EU) 2019/1155 of 20 June 2019. In particular, in its Resolution, the European Parliament has requested the European Commission to present, by March 31, 2019, "a legislative proposal establishing a European Humanitarian Visa, giving access to European territory - exclusively to the Member State issuing the visa-for the sole purpose of submitting an application for international protection" on the basis of Article 77(2)(a) of the TFEU. The Commission was expected to follow the recommendations, which provide for such visa applications to be lodged directly, by electronic means or in writing, at any consulate or embassy of the Member States; but apparently the trilogue negotiations on this matter have been abandoned and the train legislative procedure derailed, Legislative Train Schedule, EuropeAn PARLIAMENT, supra note 31.

${ }^{56}$ Decaux, supra note 4, at para. 20. See also Moreno-Lax, supra note 31, at 79. A counter-example of non-compliance with this obligation can unfortunately be found in those provisions included within the Italian "decreto sicurezza bis"—or "security decree $a$," rendered by the Italian Ministry of Interiors in June 2019-generally criminalizing rescue interventions by NGOs while saving lives off the Italian coasts, see Articles 2 and 3 of the law decree number 53 of June 14, 2019, converted into law after a harsh public debate on August 6, 2019. Quite the opposite-with regard to new narratives on migration-the same Italian Parliament hosted a public audience on July 1, 2019, to present to the vast public — also in streaming - the results of the first three and a half years of humanitarian corridors, confronting the initiative with the one experimented in Canada and in other EU States, I corridoi umanitari al Parlamento, MediTERRANEAn Hope (Aug. 1, 2019), https://www.mediterraneanhope. com/2019/07/01/i-corridoi-umanitari-al-parlamento (last visited Aug. 6, 2019). 
indefinite tomorrow ${ }^{57}$ - in full respect of the principle of solidarity among Member States called to share responsibilities and resources pursuant to Article 80 of the TFEU, ${ }^{58}$ particularly when the protection of "rights which are not theoretical or illusory, but real" 59 needs to be accessible, actionable, and effective in practice. Furthermore, States are not alone and should confront the civil society to find flexible solutions-as the best practice of the Italian humanitarian corridors shows - in line with the shared purpose of a sustainable development for all under a new dynamic and dialectic perspective characterizing the same nature of the modern international legal order. ${ }^{60}$

\footnotetext{
${ }^{57}$ Chiara Favilli, L'urgenza di un'azione umanitaria, LA RivisTa IL Mulino (Oct. 19, 2017), available at https://www. rivistailmulino.it (last visited Aug. 6, 2019).

${ }^{58}$ Munari, supra note 22 at 63; Del Guercio, supra note 20, at 398 ff.; Adelina Adinolfi, Art. 80, in COMMENTARIO BREve AI Trattati dell'Unione europea 497 (Fausto Pocar \& Maria Caterina Baruffi eds., 2d ed. 2014); GiUseppe Morgese, La SOLIDARIETÃ DEGLI STATI MEMBRI DELL'UNIONE EUROPEA IN MATERIA DI IMMIGRAZIONE E ASILO 63-120, 174-88 (2018).

${ }^{59}$ Those are the words used in the opinion by Advocate General Mengozzi, supra note 20, at para. 158 (recalling the decision of the European Court of Human Rights, Gäfgen v. Germany, App. No. 22978/05, para. 123 (June 1, 2010) and Murray v. Netherlands, App. No. 10511/10, para. 104 (Apr. 26, 2016)).

${ }^{60}$ In the suggestive vision expressed by Decaux, supra note 4 , at 11 , such a new dialectic approach should maybe persuade us to ask ourselves: "[I]f development is the new name of peace, this multi-actors' action is not a new name of international law?"

Cite this article: Ricci C (2020). The Necessity for Alternative Legal Pathways: The Best Practice of Humanitarian Corridors Opened by Private Sponsors in Italy. German Law Journal 21, 265-283. https://doi.org/10.1017/glj.2020.7
} 